\title{
ANÁLISE DO RECONHECIMENTO DE SENTENÇAS ESTRANGEIRAS NO BRASIL A PARTIR DO CASO CHEVRON (SEC 8.542/2018)
}

\author{
Analysis of Recognition of Foreign Judgments in Brazil from the Perspective of the Chevron \\ Case
}

\section{Nevitton Vieira Souza}

Doutorando em Direito Internacional e Comparado pela Faculdade de Direito da Universidade de São Paulo - USP (2018). Mestre em Direito Processual pela Universidade Federal do Espírito Santo - UFES (2015), onde graduou-se em 2013. Advogado e consultor jurídico.

Email: nevitton@usp.br.

Recebido em: 18/07/2019

Aprovado em: 09/12/2019

\begin{abstract}
RESUMO: A ação homologatória da sentença equatoriana no caso Chevron (SEC 8.542/2018) trouxe à tona debates em torno dos requisitos do juízo de delibação, inerente ao reconhecimento de sentenças estrangeiras no Brasil. Tendo em conta esse contexto, o presente artigo pretende, inicialmente, à luz dos desafios da cooperação jurídica internacional na contemporaneidade, marcada pelo incremento das relações jurídicas pluriconectadas, analisar os sistemas de reconhecimento de sentenças estrangeiras existentes na ordem jurídica brasileira, bem como os requisitos positivos e negativos do juízo de delibação. Na sequência, ao verificá-los no Caso Chevron, os limites objetivos que deveriam balizar a análise do Superior Tribunal de Justiça são desafiados por flagrantes incursões de índole substantiva, relativas às alegações de corrupção debatidas em jurisdições terceiras e de provável inexecução do futuro título executivo homologado, resultando em ausência de jurisdição brasileira. De forma conclusiva, são tecidas reflexões atinentes ao avanço da Corte, ainda que disfarçado e indireto, sobre questões de fundo, alargando as tradicionais margens da delibação em atenção a temáticas transversais, tensões e os conflitos de direitos, pertinentes às pretensões deduzidas em juízo. Destaca-se o emprego do método dedutivocomparativo, a partir de fontes bibliográficas e documentais indiretas.
\end{abstract}

Palavras-chave: Chevron. SEC 8.542/2018. Reconhecimento de sentença estrangeira. Homologação de sentença estrangeira. Juízo de delibação.

ABSTRACT: The application for recognition of the Ecuadorian judgment in the Chevron Case (SEC 8.542/2018) has brought to light debates around the requirements of the "giudizio di delibazione", inherent to the recognition and enforcement of foreign judgments in Brazil. Taking that into account, in view of the challenges of international legal cooperation, in contemporary times, marked by the increase of pluriconected juridical relations (cases with an international connection), the present article intends to analyze the systems of recognition of foreign judgments existing in the Brazilian legal order, as well as the positive and negative requirements of the "giudizio di delibazione". Then, by verifying the requirements in the Chevron Case, the objective limits, which should serve as parameters for the Superior Court of Justice's analysis, are challenged by flagrant substantive incursions, related to allegations of corruption examined in third 
jurisdictions and of probable non-enforcement of the recognised judgment, resulting in the absence of Brazilian jurisdiction. In conclusion, reflections are made on the Court's advance substantive issues, even though disguised and indirect, extending the traditional margins of the "giudizio di delibazione" in view of cross-cutting themes, tensions and rights' conflicts, underlying the claims made in court. The deductive-comparative method was used based on indirect bibliographic and documentary sources.

Keywords: Chevron Case. SEC 8.542/2018. Recognition of foreign judgments. International legal cooperation. Giudizio di delibazione.

SUMÁRIO: Introdução. 1 Juízo de delibação e seus requisitos. 2 Sistemas de reconhecimento de sentença estrangeira no Brasil. 3 O Caso Chevron: Sentença Estrangeira Contestada n. 8.542/2018. Conclusão. Referências.

\section{INTRODUÇÃO}

O reconhecimento de sentença estrangeira é um importante instrumento de cooperação jurídica internacional, visto que tem por escopo possibilitar que uma sentença produza efeitos para além do espaço jurisdicional da autoridade que a prolatou. Assim, na medida em que as fronteiras estatais se diluem face à facilidade de circulação de pessoas, bens e serviços, numa sociedade cada vez mais globalizada, as respostas jurisdicionais às relações jurídicas pluriconectadas, para serem efetivas, demandam atuação conjunta das jurisdições estatais.

Ademais de ser temática processual, está inserida no âmbito de estudo do Direito Internacional Público e do Direito Internacional Privado, uma vez que está estritamente ligada à jurisdição, em suas perspectivas interna e internacional, com normas nacionais e internacionais que a disciplinam. Nessa toada, matérias como acesso à justiça, jurisdição de proteção, forum shopping, forum non conveniens, imunidade de jurisdição, dentre outras, podem ser englobadas nos estudos atuais da jurisdição, repercutindo na circulação de decisões.

O diploma processual civil brasileiro de 2015, atento ao crescimento das relações jurídicas com elementos de conexão estrangeira, caminhou bem ao contemplar, finalmente, espaço destinado à disciplina da cooperação jurídica internacional (artigos 26 a 41), apresentando normas gerais e específicas que deverão balizar a utilização dos instrumentos de cooperação jurídica internacional no Brasil. No tocante ao reconhecimento de sentenças estrangeiras (artigos 960 a 965), em específico, o Código de Processo Civil de 2015 reforçou a abertura às normas internacionais, conferindo-lhes primazia em matéria de direito processual (artigo 13).

As sentenças estrangeiras podem produzir certos efeitos jurídicos na ordem interna sem que necessite de qualquer ato doméstico prévio, em virtude de lei, como para fins declaratórios ou probatórios. Para que possam produzir, todavia, os mesmos efeitos jurídicos que produzem na jurisdição de origem, bem como para que possam ser passíveis de execução tal como as sentenças nacionais na ordem interna, faz-se necessário que primeiro se submetam ao juízo de delibação pelas autoridades competentes. Esse juízo permite aferir se o título decisório alienígena contempla todos os requisitos formalmente estabelecidos pela legislação nacional.

Influenciado por suas origens italianas, o giudizio di delibazione é destacado por restringir a análise das autoridades nacionais sobre as sentenças estrangeiras à conferência formal de certos requisitos, legal e previamente fixados. A delibação valoriza a coisa julgada estrangeira, reforçando a confiança na prestação jurisdicional do órgão prolator do ato, seja estatal ou não. Essa sistemática é tradicionalmente contraposta ao modelo revisional de mérito, cujas referências históricas remontam à França e Bélgica, que permite a reabertura de exame substantivo sobre o mérito da decisão alienígena. 
Na análise do caso Chevron, SEC n. 8.542, julgado pela Corte Especial do Superior Tribunal de Justiça em 2017, publicado em 2018, observa-se uma tensão constante entre a contenção ou o avançar dos julgadores sobre questões substantivas, questões que poderiam extrapolar, aparentemente, o contencioso reduzido peculiar à ação de homologação de sentença estrangeira - tais como a análise da engenharia societária da Chevron; das alegações de corrupção no processo original equatoriano, aferidas por jurisdição terceira (a norte-americana); da exequibilidade do futuro título executivo, caso homologado.

Observa-se, nesse contexto, que o juízo de delibação, como concebido, sofre pressões de temáticas transversais, tensões e conflitos de direitos, subjacentes às pretensões deduzidas em juízo e que podem aflorar, também, durante a análise do pedido de reconhecimento da sentença estrangeira.

À vista do cenário delineado, o presente trabalho foi dividido em três partes. Na primeira, serão vistos os requisitos do juízo de delibação, conforme elencado pela legislação vigente. $\mathrm{Na}$ segunda, os diferentes sistemas de reconhecimento de sentenças estrangeiras em vigor no ordenamento brasileiro serão delineados, a saber: sistema ordinário (por meio da ação de homologação), sistema mercosulino (por meio da carta rogatória), sistema arbitral (regido pela Convenção de Nova York de 1958) e sistema extraordinário (por meio do exame de validade).

Por fim, na terceira e última parte, será apresentado o caso Chevron, SEC n. 8.542/2018, no qual é possível verificar concretamente os requisitos exigidos para a homologação de sentença estrangeira no Brasil, bem como se destaca a discussão relativa aos limites do juízo de delibação, posto que o processo original que deu origem à sentença homologanda trouxe à tona questões de fraude e corrupção. Na tentativa de manter a cognição restritiva do juízo de delibação, a Corte Especial do Superior Tribunal de Justiça concentrou-se na aferição do interesse processual dos requerentes e na existência de jurisdição nacional.

Pontua-se, em tempo, que o método dedutivo-comparativo foi adotado na presente pesquisa, realizada a partir de fontes bibliográficas e documentais indiretas.

\section{JUÍZO DE DELIBAÇÃO E SEUS REQUISITOS}

Por juízo de delibação se compreende a análise estrita, formal e sem se visitar o mérito da decisão estrangeira, apenas com o objetivo de constatar a concorrência ou não de requisitos previamente estabelecidos. A delibação consiste em um modo de se reconhecer a sentença alienígena, modo este que goza de maior adesão entre os ordenamentos jurídicos e de maior credibilidade entre a doutrina mais moderna (BELTRAME, 2009). Originário da Itália (giudizio di delibazione), contrapõe-se ao modelo de revisão de mérito em vigor por muito tempo na França e na Bélgica (BARBOSA MOREIRA, 2011).

O juízo de delibação é compatível tanto com o regime incidental de reconhecimento da sentença estrangeira - exercido pelo próprio juízo da execução em fase anterior a esta - quanto com o regime de reconhecimento autônomo, mediante processo formal prévio e à parte da execução. O Brasil já vivenciou as duas sistemáticas. O regime incidental de reconhecimento da sentença estrangeira foi adotado pelo primeiro diploma legal brasileiro a disciplinar a matéria, o Decreto n. 6.982/1878, o qual estabeleceu a figura do "cumpra-se", cuja competência era do juízo da execução. O "cumpra-se" somente era posto sobre título forasteiro após a verificação dos requisitos positivos e negativos. Essa verificação era precisamente o exercício do juízo de delibação. Com a edição da Lei n. 221/1894, o juízo de delibação das sentenças estrangeiras passou a ser exercido por meio de processo autônomo, à parte e prévio à execução do título decisório, concentrado no Supremo Tribunal Federal. A tal processo deu-se o nome de homologação. Não se confundem, portanto, homologação com juízo de delibação ${ }^{1}$.

\footnotetext{
1 "Em uma ou outra hipótese, porém, o sistema da delibação não se encontra na forma pela qual a sentença estrangeira é reconhecida, mas nos requisitos exigidos para o seu reconhecimento, que traduzem a concepção feita por Revista de Direito Brasileira | Florianópolis, SC | v. 28 | n. 11 | p.351-366 | Jan./Abr. 2021
} 
Importa destacar, no que tange aos requisitos positivos e negativos do juízo de delibação, que o CPC/15, com pouca variação, contempla os parâmetros já existentes no histórico-normativo brasileiro. Sendo estes constantes no Regimento Interno do STJ (RISTJ) (art. 2016-D e 216-F), o qual reflete o estabelecido pela Resolução n. 9/2004 (art. $5^{\circ}$ e $6^{\circ}$ ). Esta, por sua vez, reproduz o disposto nos artigos 216 e 217 do Regimento Interno do STF, que ao seu turno espelha o conteúdo dos artigos 15 e 17 da Lei de Introdução às Normas do Direito Brasileiro. Esta, também, bebe na fonte de outro diploma, o Código de Processo Civil de 1939, artigos 791 e 792. Ao se comparar o CPC de 1939 com o Decreto n. 6.982/1878, o primeiro diploma nacional a versar sobre a matéria, também é possível observar identidade entre os requisitos (art. $1^{\circ}$ e $2^{\circ}$ ). Conclui-se, portanto, existir certa estabilidade, com pouca variação, nos requisitos positivos e negativos que norteiam o juízo de delibação de sentenças estrangeiras a serem reconhecidas no Brasil.

Atualmente, os requisitos que devem balizar o juízo de delibação são seis e estão estabelecidos pelos artigos 963 e 964 do CPC/15. Estes podem ser divididos em positivos e negativos, sendo que os primeiros precisam ter a presença confirmada no título decisório a ser reconhecido, enquanto os segundos não podem constar nas sentenças estrangeiras (RAMOS, 2015).

O primeiro requisito legal a ser verificado é se a sentença alienígena foi expedida por autoridade competente - art. 963, I, CPC/15; e art. 216-D, I, do RISTJ. Com isso, a competência da autoridade prolatora deve ser analisada sob dois prismas, um da lei a que ela está vinculada e outro das normas de competência internacional assentadas pela lei brasileira. Pelo primeiro, devese comprovar que a autoridade que prolatou a sentença tinha competência segundo as leis às quais está vinculada, não importando se sua natureza é jurídica ou administrativa - como acontece no Japão, onde prefeitos podem expedir sentenças de divórcio (TANAKA, 2005).

Em um segundo prisma, o requisito da competência da autoridade está relacionado a sua competência internacional para realizar tal ato, esta entendida no sentido negativo, isto é, olhando para o que prescreve a legislação nacional, no exercício do juízo de delibação o magistrado deverá observar se a matéria tratada pela sentença estrangeira não está incluída nas matérias de competência exclusiva da jurisdição brasileira - nos termos do art. 23 do CPC/15. Caso se trate de matéria na qual o Brasil declara ter competência internacional exclusiva, o título decisório estrangeiro não será reconhecido. Caso se trate de matéria de competência internacional concorrente (art. 22 e 23 do CPC/15), do ponto de vista legal, não haverá óbice ao reconhecimento. Inclusive, nessa hipótese, caso haja processo idêntico em trâmite na jurisdição brasileira (litispendência), este não impedirá o reconhecimento da sentença estrangeira (art. 24, parágrafo único do $\mathrm{CPC} / 15)$.

O segundo requisito exigido para o reconhecimento da sentença alienígena é a comprovação de que houve, no processo originário estrangeiro, a citação regular das partes, ainda que se tenha verificada a revelia - art. 963, II, do CPC/15; e art. 216-D, II, do RISTJ. Requisito que está diretamente ligado ao princípio do devido processo legal, deve-se ter em conta que o cumprimento de citações está sujeito aos princípios da lex fori e da lex diligentiae (HILL, 2007). Pelo primeiro, os atos praticados na mesma jurisdição estrangeira em que se desenvolve o processo deve respeitar as normas deste foro relativas à citação. Pelo princípio da lex diligentiae, por sua vez, os atos a serem praticados fora da jurisdição em que se desenvolve o processo originário devem respeitar as normas do local.

O terceiro requisito é que a sentença estrangeira, para ser reconhecida no Brasil, deve ser eficaz no país de origem - art. 963, III, do CPC/15. Critério com base lógica, uma vez que o que se pretende com a cooperação jurídica internacional por meio do reconhecimento de sentenças estrangeiras é que os efeitos destas sejam extensíveis a outros espaços jurisdicionais forasteiros.

determinado ordenamento jurídico da natureza da sentença estrangeira antes de homologada. A existência, ou não, de um juízo formal de homologação não interfere no conteúdo do exame do ato judicial alienígena" (GRECO FILHO, 1978, p. 91-92). 
Não faria sentido permitir que uma sentença tenha eficácia fora do Estado no qual foi prolatada, enquanto é incapaz para produzir efeitos na sua ordem jurídica originária. Do mesmo modo, não pode o título decisório alienígena produzir mais efeitos extraterritoriais do que territoriais. Destarte, deve-se fazer prova de que a sentença a ser reconhecida está apta a produzir efeitos na sua ordem jurídica natal, hipótese na qual poderá ser reconhecida e produzir efeitos no Brasil.

O quarto requisito do juízo de delibação brasileiro é que a sentença alienígena não fira a coisa julgada brasileira - art. 963, IV, do CPC/15. Apesar de não constar textualmente no RISTJ e na LINDB, este requisito já estava implícito na ofensa à ordem pública, inclusive segundo a jurisprudência do STJ (SEC n. 1.271/2011). O CPC/15 houve por bem destacar esse requisito, a fim de dar maior visibilidade. Isso porque, embora a litispendência internacional não implique em impedimento ao reconhecimento de sentenças estrangeiras (art. 24, parágrafo único do CPC/15), uma vez que no processo nacional se alcance decisão agasalhada pela coisa julgada, esta passa a configurar obstáculo insuperável.

O quinto requisito legal é a apresentação de tradução oficial da sentença a ser reconhecida, salvo se houver disposição diversa em norma internacional - art. 963, V, CPC/15. A tradução é imprescindível, visto que em todos os processos em trâmite no Brasil se exige o uso da língua portuguesa (art. 192, CPC/15), o que está diretamente ligado ao princípio constitucional de publicidade na atuação pública (art. 37, CRFB/88). Assim, a tradução oficial, firmada por tradutor juramentado, é dispensada no caso de tramitação por via diplomática ou autoridade central (art. 192, parágrafo único do CPC/15). Ademais, conforme art. 41 do CPC/15, são presumidos autênticos os documentos tramitados por meio de autoridade central ou diplomática. Reitera-se, portanto, que a apresentação de tradução não pode ser dispensada, sob pena de prejudicar a publicidade dos atos processuais, mas a exigência de que seja juramentada ou expedida por outro meio oficial é de livre disposição infraconstitucional.

Por fim, o sexto e último requisito essencial ao juízo de delibação é a inexistência de ofensa à ordem pública - art. 963, VI, do CPC/15. Tal critério, existente desde o primeiro diploma brasileiro a versar sobre o reconhecimento de sentença estrangeira, é reconhecidamente fluido e cambiante em função do contexto jurídico-social ${ }^{2}$. Por isso, seu conteúdo não é explicitado pelo legislador em rol taxativo, configurando atribuição das cortes sua aferição caso a caso (KNIJNIK, 2008). Pode-se afirmar, contudo, que a ordem pública enquanto filtro do reconhecimento de decisões alienígenas tem como escopo impedir que situação jurídica defesa ao ordenamento jurídico interno ingresse por via indireta. Ainda aqui, na aferição do requisito da não ofensa à ordem pública, o juiz que exerce a delibação não está autorizado a adentrar o mérito da decisão originária com vistas a exercer novo juízo de valor sobre as demandas originárias. A análise é essencialmente formal, no sentido de verificar se o conteúdo já decidido pela autoridade competente estrangeira é juridicamente compatível com o ordenamento jurídico brasileiro.

Tendo sido apresentados os requisitos balizadores do juízo de delibação, resta evidenciar os modos pelos quais este será realizado, revelando os distintos sistemas de reconhecimento de decisões estrangeiras existentes no Brasil.

\section{SISTEMAS DE RECONHECIMENTO DE SENTENÇA ESTRANGEIRA NO BRASIL}

As normas que disciplinam o reconhecimento de sentenças estrangeiras no Brasil estão espalhadas em distintos diplomas normativos, nacionais e internacionais, formando um complexo emaranhado normativo que requer sistematização, a fim de se facilitar a compreensão sobre o caminho processual pelo qual as decisões estrangeiras precisam trilhar para produzirem efeitos no âmbito doméstico.

\footnotetext{
2 “O princípio da ordem pública é conceitual, filosófico, moral, indefinível, elástico, relativo, alterável, volúvel, sempre na dependência do conceito, da opinião, do sentimento, da sensibilidade média de um grupo social em determinada época que vai encontrar sua expressão clássica na sentença judicial" (DOLINGER, 1979, p. 10).
} 
Esse caminho não é unívoco, comportando peculiaridades a depender da origem do título decisório alienígena. Desse modo, a sistematização normativa revela a existência de, ao menos, quatro sistemas de reconhecimento de decisões estrangeiras estruturados, a saber: sistema ordinário (por meio da ação de homologação), sistema mercosulino (por meio da carta rogatória), sistema arbitral (regido pela Convenção de Nova York de 1958) e sistema extraordinário (por meio do exame de validade). Ademais, ainda é possível vislumbrar a existência de sistemas bilaterais, frutos de tratados desta natureza (SOUZA, 2015).

O sistema ordinário de reconhecimento de sentença estrangeira ocorre por meio da ação de homologação, a qual consiste em ato formal e autônomo prévio à execução da decisão alienígena. Atualmente, as bases infraconstitucionais da ação de homologação estão no CPC/15, art. 961 e 960; LINDB, art. 15, "e"; e RISTJ, art. 216-B. Quanto à Constituição Federal, apenas se limita a estabelecer a competência do STJ para o seu processamento e julgamento, sem que contenha norma expressa que exija a obrigatoriedade da ação homologatória (art. 105, I, “i”).

$\mathrm{O}$ legislador do CPC/15, por assim dizer, alinhou-se ao posicionamento segundo o qual a ação homologatória não é obrigatória, prescrevendo no art. 961 que embora a homologação seja uma exigência ordinária a ser cumprida pela sentença estrangeira que se pretenda que produza efeitos no Brasil, tal exigência pode ser ressalvada por norma nacional ou internacional. Assim, a sistemática apresentada pelo CPC/15 funciona como um sistema ordinário de reconhecimento de sentença estrangeira.

O sistema ordinário tem seu procedimento desenvolvido no STJ, tribunal constitucionalmente competente para processar e julgar a ação de homologação de sentença estrangeira. O CPC/15, tal como seu antecessor, prescreve que deverão ser observadas as disposições do Regimento Interno do STJ (RISTJ), de modo que o processamento da ação de homologação seguirá o rito estabelecido pelos artigos 216-A a 216-N do RISTJ.

A ação de homologação é de jurisdição contenciosa ${ }^{3}$, com amplitude cognitiva reduzida em função do estrito exercício do juízo de delibação, a fim de aferir o cumprimento ou descumprimento dos requisitos legais acima apresentados. Conforme o art. 216-A, é atribuição da Presidência do STJ homologar decisão estrangeira, salvo se houver contestação ou impugnação, quando o processo será distribuído para ser julgado pela Corte Especial, bem como nomeado relator.

Ao fim do contraditório, homologada a sentença estrangeira, será extraída dos autos carta de sentença, a qual deverá ser apresentada pela parte interessada no Juízo Federal competente para a execução de sentença nacional de igual teor, conforme art. 965 do CPC/15 e art. 216-N do RISTJ, a fim de instaurar processo de execução nos termos da legislação processual em vigor.

Apesar de ter sido o CPC/15 que explicitou textualmente a abertura do sistema processual brasileiro (art. 13) - reconhecendo, no que tange ao reconhecimento de sentença estrangeira, a possibilidade de que outras normas, nacionais e internacionais, excepcionem a ação de homologação e estabeleçam outros mecanismos (art. 961, caput) -, a jurisprudência ${ }^{4}$ já admitia a tramitação de pedidos de reconhecimento por meio de cartas rogatórias, tendo como base normativa

\footnotetext{
${ }^{3}$ Conforme análise de Greco Filho: "Temos, portanto, que a homologação é uma ação, pedido de tutela jurisdicional constitutiva [ação constitutiva de eficácia executiva]. Para Amílcar de Castro trata-se de processo de jurisdição voluntária, porque não haveria contenciosidade ou lide a compor. Rendenti, porém, a considera de jurisdição contenciosa, no que coincide com quase a unanimidade da doutrina. A terminologia do Regimento Interno do Supremo Tribunal Federal é a dos processos contenciosos, porque utiliza as expressões "citar o executado", "contestar o pedido", "citação das partes" etc. Optamos, também, pela orientação de que se trata de processo de jurisdição contenciosa, porquanto dirime a controvérsia pretensão à homologação - resistência à pretensão à homologação. Trata-se de uma contenciosidade limitada, porque não se renova o litígio que gerou a sentença, mas parece incontestável o conflito de interesses diante da possibilidade de formulação de pretensão à não-homologação" (GRECO FILHO, 1978, p. 112).

${ }^{4}$ Nesse sentido: BRASIL. Supremo Tribunal Federal. Reclamação Constitucional (RCL) no 717-RS. Ministro Presidente do STF. Data de Julgamento: 30/12/1997. Data de Publicação: 04/02/98.
} 
o Protocolo de Cooperação e Assistência Jurisdicional em Matéria Civil, Comercial, Trabalhista e Administrativa, conhecido como Protocolo de Las Leñas $I^{5}$, especificamente seu art. 19. À vista disso, o modo próprio de se reconhecer as sentenças provenientes dos Estados que compõem o Mercosul, pela via da carta rogatória, é o sistema mercosulino.

O processamento do pedido de reconhecimento por meio de carta rogatória simplifica o procedimento, tornando-o mais célere e menos custoso, por isso constitui instrumento de integração dos países do Cone Sul. Em seu art. 20, o Protocolo elenca os requisitos indispensáveis ao reconhecimento da decisão alienígena, os quais apresentam equivalência com os requisitos constantes na legislação nacional, já mencionados no tópico anterior. Ademais, destaca a possibilidade de reconhecimento parcial da sentença estrangeira.

Como exceção à regra geral estabelecida pelo CPC/15 (art. 24), no âmbito do Protocolo de Las Leñas é reconhecida a litispendência internacional, de modo que obstará o reconhecimento de sentenças estrangeiras entre os Estados-partes, por força do art. 22.

No tocante ao procedimento, o art. 24 do Protocolo estabelece que caberá ao Estado requerido estabelecer o rito do reconhecimento, observados os parâmetros convencionais fixados. No Brasil, portanto, cumprirá ao CPC/15 e ao RISTJ regularem o processo, aplicando-lhe as normas atinentes às cartas rogatórias. Importa destacar, inclusive, que o $\mathrm{CPC} / 15$ já traz em seu texto o reconhecimento pela via rogatória (art. 961, caput), demonstrando a influência da norma internacional mercosulina.

A simplificação principal do sistema mercosulino, ao permitir a tramitação por meio de carta rogatória, é que a parte interessada poderá requerer, no próprio processo de origem, que a mesma autoridade que prolatou a sentença expeça carta rogatória - conforme sua processualística nacional. Intermediado por autoridades centrais, o pedido será direcionado à jurisdição onde se pretende que os efeitos da sentença sejam projetados, sem que a parte estrangeira interessada tenha que constituir advogado e abrir pessoalmente ação homologatória no Brasil.

O Ministério da Justiça, autoridade central brasileira nos termos do art. $26, \S 4^{\circ}$, do CPC/15, por intermédio do Departamento de Recuperação de Ativos e Cooperação Jurídica Internacional (DRCI), é o responsável por receber e dar prosseguimento aos pedidos de cooperação jurídica internacional no Brasil. Destarte, recebida a carta rogatória com o pedido de reconhecimento de sentença estrangeira, será o órgão responsável por tomar as providencias necessárias para a tramitação do pedido no STJ.

No STJ, a tramitação dos pedidos de carta rogatória também é atribuição da Presidência, salvo quando ocorrer impugnação (art. 216-O do RISTJ). De natureza semelhantemente contenciosa, o rito a ser seguido internamente está previsto nos artigos 216-O ao 216-X do RISTJ, e será tal qual o já mencionado para a ação de homologação, inclusive o posterior processo de execução na Justiça Federal.

Em relação às sentenças arbitrais, o art. $960, \S^{\circ}$, do $\mathrm{CPC} / 15$ converge com o disposto no art. 34 da Lei Brasileira de Arbitragem (LBA), Lei n. 9.307/96, no sentido de privilegiar a aplicação de normas internacionais existentes na matéria. Na omissão da norma internacional, a LBA será aplicável preferencialmente às normas processuais ordinárias do CPC, que são subsidiárias. Destarte, constata-se que ao reconhecimento de sentenças arbitrais estrangeiras será aplicada a Convenção de Nova York de 1958 (CNY), promulgada no Brasil pelo Decreto n. 4.311/2002.

O sistema arbitral de reconhecimento de sentenças estrangeiras se distingue dos demais notadamente por apresentar requisitos próprios que devem nortear o juízo de delibação. Os requisitos apresentados pela $\mathrm{CNY}$, em seu art. $5^{\circ}$, são, contudo, muito semelhantes aos

\footnotetext{
${ }^{5}$ Promulgado pelo Decreto n. 2.067, de 12 de novembro de 1996. Assinado pelo Brasil em 27 de junho de 1992 , no âmbito do Mercosul.
} 
estabelecidos pela LBA, em seus artigos 38 e 39 (ARAUJO, 2017) ${ }^{6}$. A bem da verdade, foram por ela inspirados, uma vez que somente em 2002 o Brasil promulgou a CNY (LEMES, 2006). O rito processual a se desenvolver no STJ, sob às normas do RISTJ, será semelhante ao da ação homologatória de sentença não arbitral estrangeira, já trabalhada no sistema ordinário.

O sistema extraordinário de reconhecimento de sentença estrangeira, diversamente dos anteriores, não é autônomo e prévio ao processo de execução. Tampouco é de competência exclusiva e concentrada do STJ, submetendo-se às normas regimentais da Corte. Nele, o juízo de delibação é realizado pelo mesmo juiz competente para executar a sentença estrangeira, como um incidente processual do processo de execução, ou ainda em outro processo no qual seja suscitada ${ }^{7}$.

Conforme já demonstrado acima, a nova regulamentação processual civil do CPC/15 explicitou que a ação homologatória não é absolutamente indispensável ao reconhecimento de decisões estrangeiras no Brasil (art. 961, caput). Ademais de dispor que normas nacionais e internacionais podem excepcionar a ação homologatória, o próprio CPC/15 traz hipótese de dispensa de procedimento autônomo e prévio à execução da sentença alienígena (art. $961, \S \S 5^{\circ} \mathrm{e}$ $6^{\circ}$; e art. 962).

Embora haja dispensa de ação homologatória, ou outro procedimento autônomo e prévio, não há que se falar em suplantação do juízo de delibação e sua aferição de compatibilidade formal da sentença estrangeira com a ordem jurídica nacional brasileira ${ }^{8}$. Os próprios dispositivos reiteram a necessidade de que a autoridade judicial exerça um "exame de validade" do título decisório alienígena - "examinar a validade da decisão, em caráter principal ou incidental" ( $\$ 6^{\circ}$, art. 961 , $\mathrm{CPC} / 15)$ e "ter sua validade expressamente reconhecida pelo juiz competente para dar-lhe cumprimento" ( $\$ 4^{\circ}$, art. $\left.962, \mathrm{CPC} / 15\right)$.

Dito isto, fica evidente existência de impropriedade por parte da legislação ordinária quando do estabelecimento dos requisitos balizadores do juízo de delibação, posto que não são "requisitos indispensáveis à homologação da decisão", como consta no CPC/15 e nos demais diplomas pertinentes. A bem da verdade, deveriam dizer "requisitos indispensáveis ao juízo de delibação", visto que aplicáveis tanto à ação de homologação, como à carta rogatória que tramita pedido de reconhecimento e ao exame de validade, nas hipóteses de dispensa de procedimento autônomo e prévio de reconhecimento (SOUZA, 2015).

\section{O CASO CHEVRON: SENTENÇA ESTRANGEIRA CONTESTADA N. 8.542/2018}

A Chevron é uma empresa americana, sediada nos Estados Unidos, considerada uma das maiores do setor energético, principalmente no que se refere à exploração de petróleo. Conforme expresso em seu site oficial, a Chevron atua em vários países ao redor do mundo ${ }^{9}$. O caso que será analisado trata de uma condenação bilionária sofrida por uma subsidiária da Chevron no Equador, num processo que apesar de ter tramitado perante a Justiça equatoriana, repercutiu também na

\footnotetext{
6 "Uma breve análise comparativa entre os requisitos para o reconhecimento de laudos arbitrais estrangeiros impostos pela Lei de Arbitragem (arts. 38 e 39 da Lei 9.307/96), de um lado, e pela Convenção de Nova Iorque (artigo V), de outro, conduz facilmente à percepção de que são bastante semelhantes" (VERÇOSA, 2003, p. 5).

${ }^{7}$ Nesse diapasão, oportuna a assertiva de Greco Filho, no sentido de que "o sistema de delibação é compatível com um regime de reconhecimento incidental de sentença ou de processo formal de homologação" (GRECO FILHO, 1978, p. 91).

${ }^{8}$ Versando sobre a modalidade automática de reconhecimento, como a existente no âmbito da União Europeia, Marcela Pereira pontua que também nessa situação não se vislumbra eliminação de aferição dos requisitos formais previamente estabelecidos: "No reconhecimento automático, o juízo da idoneidade da sentença estrangeira pode ser feito por qualquer um, o que não implica a ausência de condições legais; dispensa-se o procedimento oficial, a formalidade, mas não a adequação da sentença estrangeira aos requisitos da lei. Abole-se a homologação; exige-se a delibação" (PEREIRA, 2010, p. 38).

${ }^{9}$ Disponível em < https://www.chevron.com/worldwide>. Acesso em: $1^{\text {o }}$ jul. 2019.
} 
americana - com sucessivas acusações e suspeitas de fraude e corrupção - e em outras jurisdições estrangeiras - em pedidos de reconhecimento no Brasil, Argentina e Canadá.

$\mathrm{O}$ contexto fático da sentença equatoriana objeto do pedido de reconhecimento se refere a acusações que pesam contra a Chevron em relação a profundos danos ambientais a mais de 30 mil pessoas, na região amazônica ao norte do Equador, grande parte de responsabilidade da Texaco Inc., que fora comprada pela Chevron ${ }^{10}$. A decisão condenatória obtida em segunda instância, na Sala Única da Corte Provincial de Sucumbíos, reconheceu a existência de danos ambientais e condenou a Chevron em mais de 18 bilhões de dólares, sendo: i) US\$8.6 bilhões por reparação a danos ambientais; ii) US $\$ 8.6$ bilhões por danos punitivos; iii) $10 \%$ sobre o valor da condenação, a título de "prêmio aos autores", com base na lei ambiental equatoriana; iv) 0,1\% de honorários advocatícios.

$\mathrm{Na}$ ação homologatória, sob a rubrica da Sentença Estrangeira Contestada (SEC) n. 8.542/2018, figuram uma lista de 46 requerentes, sendo a requerida a empresa americana Chevron Corporation. Após tentativas frustradas de citação da requerida no Brasil, a Chevron Corporation foi citada na Califórnia, Estados Unidos da América, por meio de carta rogatória. Em sede de contestação, foram deduzidos oito pontos, a saber:

a) irregularidade na representação processual dos autores, pois os advogados brasileiros não teriam poderes para ajuizar esta ação; b) falta de jurisdição brasileira para a homologação desta sentença, pois a Chevron não possui domicílio nem bens no Brasil, de onde deflui também sua ilegitimidade passiva; c) falta de interesse de agir dos autores e do Estado brasileiro para a homologação; d) impossibilidade de supressão do princípio da personalidade jurídica, haja vista que a Chevron Brasil é subsidiária em sétimo grau da Chevron Corporation; e) falta de eficácia, no Equador, da sentença que os autores pretendem homologar, ante a existência de decisão do Tribunal Arbitral em Haia, que obriga o Equador a não executar a sentença nem dentro, nem fora daquele país; f) não ocorrência do trânsito em julgado da sentença equatoriana; g) inexistência dos danos ambientais que a sentença estrangeira alegadamente objetiva reparar; h) construção artificial de tais danos no processo, mediante fraude e violação do devido processo legal, da segurança jurídica e da ordem pública (BRASIL, 2018, p.3).

Em momento posterior, a requerida apresentou aditivos à contestação, que de modo sintético visavam apontar: i) pedidos de reconhecimento da mesma sentença equatoriana também em mais duas jurisdições estrangeiras: a) Canadá: onde o tribunal nacional decidiu pela suspensão do processo, com base na inexistência de atuação da empresa Chevron Corporation no pais, nem mesmo existindo ativos seus no país; b) Argentina: o tribunal local cassou o arresto de bens que cautelarmente recaia sobre as subsidiárias indiretas da Chevron no país; ii) pareceres também apresentados perante a Justiça americana, indicando inexistência de dano ambiental e ocorrência de fraude; iii) modificação parcial da sentença equatoriana, com exclusão dos danos punitivos, pelo que o valor da causa seria reduzido em quase metade; iv) sentença arbitral parcial proferida no Tribunal de Haia.

Oportunizada réplica aos requerentes, os seguintes pontos foram versados:

\footnotetext{
${ }^{10}$ Sobre os processos à época movidos perante a Texaco Inc., Ricardo Coelho assevera: "Face a uma auditoria ambiental que confirmava a sua responsabilidade por vários delitos ambientais, a empresa negociou diretamente com o governo equatoriano uma compensação de 40 milhões de dólares, entre 1995 e 1998 . O pagamento desta compensação libertava a empresa de qualquer responsabilidade futura para com o governo equatoriano. Simultaneamente, a petrolífera comprometeu-se a limpar a contaminação provocada, o que fez sem qualquer monitorização governamental, num processo denunciado como negligente pelas populações locais. As comunidades indígenas e de colonos afetadas nunca foram consultadas, nem na elaboração da auditoria ambiental, nem na negociação do acordo entre o governo e a Texaco" (COELHO, 2016, p.102-103).
} 
a) inexistência de violação à ordem pública; b) regularidade da representação processual mas, caso se entenda de modo contrário, requerem a concessão de prazo para a regularização dos instrumentos de mandato; c) perda parcial e superveniente de objeto, já que afastada a condenação pelos danos punitivos; d) limites do juízo delibatório da ação de homologação; e) inequívoca jurisdição brasileira; f) legítimo interesse; g) trânsito em julgado da decisão homologanda; h) impossibilidade de suspensão desta ação, pois nem sequer são partes no procedimento arbitral instaurado no Tribunal de Haia; i) inexistência de quitação; j) legitimidade passiva da Chevron; k) inexistência de fraude na condução do processo no Equador e ausência de juntada das peças da ação que tramitou nos EUA, na qual se concluíra pela ocorrência das citadas irregularidades; 1) existência de danos ambientais; $m$ ) desrespeito, pela Chevron, da soberania do Estado equatoriano; n) distorção dos argumentos apresentados pela Chevron, que são baseados em decisões judiciais estrangeiras não homologadas pelo Brasil (BRASIL, 2018, p.4).

Em sua manifestação, o representante do Ministério Público Federal se pugnou pela denegação do pedido de homologação, tendo como fundamento de seu parecer a existência de decisão na Justiça norte-americana no sentido de reconhecer comprovada ocorrência de fraude e corrupção no processo que ensejou a sentença equatoriana, inclusive envolvendo peritos e magistrado. Para o Parquet, tal comprovação produzida pela Justiça norte-americana levaria a ser ofensivo à ordem pública reconhecer a sentença equatoriana.

$\mathrm{Na}$ Corte Especial, a ação homologatória passou a ser de relatoria do Min. Luís Felipe Salomão, após o Min. Felix Fisher se declarar suspeito, por motivo de foro íntimo. Em seu voto, que se sagrou vencedor por unanimidade, é possível verificar que o ministro-relator divide a decisão em duas partes.

$\mathrm{Na}$ primeira parte, a decisão se concentra em reunir os fatos alegados pelas partes, evidenciando três pontos principais: i) embora a sentença equatoriana tenha sido proferida em face da empresa Chevron Corporation, os fatos pelos quais foi responsabilizada foram praticados pela Texaco Inc., antes de ter sido fundida com a Keepep Inc., subsidiária independente da Chevron no Equador, em 2001; ii) a existência de diversas ações nos Estados Unidos da América, inclusive de produção antecipada de provas (discovery actions), tendo como fundamento a ocorrência de fraudes e atos de corrupção no processo original, no Equador, algumas já contando com decisões em primeiro e segundo grau; iii) procedimento arbitral perante o Tribunal de Haia, o qual já conta com sentenças imputando ao Estado do Equador a adoção de medias no sentido de que a sentença homologanda não produza efeitos interna ou externamente.

$\mathrm{Na}$ segunda parte da decisão é analisada a presença dos requisitos formais para a homologação, nos termos do que foi desenvolvido nos tópicos anteriores do presente trabalho. Afirma o relator que estão presentes a cópia da sentença, devidamente autenticada pela autoridade consular, acompanhada por tradução oficial. Da mesma forma, a existência de coisa julgada formal restou comprovada, bem como a sentença a ser homologada gozar de produção de efeitos na jurisdição equatoriana.

Em continuidade à verificação dos requisitos formais da ação de homologação, restou comprovada a regularidade da cadeia de representação dos requerentes, afastando-se as alegações da requerida em sentido contrário. Ao se debruçar sobre as condições da ação e os pressupostos processuais, todavia, o Tribunal aponta inconsistência no tocante à existência de interesse de agir dos requerentes e de exercício jurisdição brasileira.

No que tange ao exercício da jurisdição brasileira, aponta-se para o princípio da efetividade, segundo o qual os Estados devem evitar exercer sua jurisdição de forma exorbitante, restringindo-a às demandas com as quais guarde razoável conexão ou proximidade (RUSSELL, 1993). Tal princípio é tido em conta especialmente quando da definição das hipóteses de jurisdição internacional absoluta e concorrente de um Estado, como o constante nos artigos 21, 22 e 23 do 
CPC/15. A decisão, entretanto, afirma a necessidade de se aferir, no caso concreto, a existência de jurisdição brasileira a partir de um interesse jurídico do Estado brasileiro, tendo por base o pedido e a causa de pedir deduzidos.

Ao realizar essa análise no pedido de reconhecimento da sentença equatoriana contrária à Chevron Corporation, o Tribunal conclui que o título decisório alienígena "não envolve partes brasileiras ou domiciliadas no país, tampouco a lide originária se refere a fatos ocorridos no Brasil, nem a sentença homologanda impôs qualquer obrigação a ser cumprida em território nacional" (BRASIL, 2018, p.21).

De fato, os requerentes não incluíram no polo passivo da ação de homologação a Chevron Brasil Petróleo Ltda., embora seu endereço tenha sido apontado na exordial como o de situação da Chevron Corporation, incluída como requerida. Os autos comprovam, inclusive, que houve recusas da Chevron Brasil em receber a citação, posto que não se confundiam as personalidades jurídicas. A citação somente foi efetivada por meio de carta rogatória, direcionada à Califórnia, Estados Unidos da América, sede da requerida.

O acórdão marca a diferença entre sociedades subsidiárias, que possuem personalidades jurídicas e patrimônio próprios, das filiais, sucursais ou agências, que por sua vez seriam desdobramentos organizacionais de uma sociedade principal, não gozando de personalidades jurídicas próprias. Destarte, por ser a Chevron Brasil uma subsidiária de sétimo grau da Chevron Corporation, norte-americana, não seria possível imputar débitos de uma sociedade a outra. Tampouco seria possível cogitar execução da sentença estrangeira eventualmente homologada em face da Chevron Brasil, pois esta não participou da ação originária, não tendo contra si título decisório

Reforçando os limites da contenciosidade reduzida pertinente ao juízo de delibação, são apresentados julgados do próprio Tribunal, a fim de corroborar o impedimento de imputar responsabilidade a sociedade diversa, ainda que pertencendo ao mesmo grupo econômico, quando se tratar de subsidiária. Na decisão colhida da Segunda Seção (AgRg no CC 138.936/2015), restou decidido que mesmo em relação à execução trabalhista, não se pode avançar sobre patrimônio de empresa subsidiária integral ligada a que passa por recuperação judicial. O fundamento decorre da autonomia e independência patrimonial e de personalidade jurídica. Do julgado extraído da Primeira Turma, os ministros concluíram que "o simples fato de duas empresas pertencerem ao mesmo grupo econômico, por si só, não enseja solidariedade passiva em execução fiscal" (AgRg no Ag 1.415.293/2012).

Destarte, a Corte Especial do STJ se posicionou pela impossibilidade de que uma sociedade subsidiária, ainda que pertencente ao mesmo grupo econômico da sociedade principal, responder pelas responsabilidades ambientais desta última. E esse consistiria, no julgar da Corte, o interesse apresentado pelos requerentes, visto que, uma vez tendo conseguido a homologação da sentença equatoriana no Brasil, estariam abertas as vias da execução perante o Judiciário nacional. Ademais, eventual tentativa de executar a decisão em face da Chevron Brasil, antecipam os ministros, não seria viável por ferir o devido processo legal, posto que tanto a jurisprudência como a doutrina ${ }^{11}$ são majoritariamente no sentido de que não se pode promover execução contra quem não tenha participado da fase ou do processo de conhecimento.

Tendo em vista as impossibilidades processuais verificadas no pedido de homologação, bem como em relação à eventual tentativa de execução perante a Justiça brasileira, a Corte Especial chega à conclusão de que falta jurisdição brasileira no caso concreto. Essa visão utilitarista do exercício jurisdicional é resumida nos seguintes pontos:

\footnotetext{
${ }^{11}$ A decisão cita a doutrina de: GRECO FILHO, Vicente. Homologação de sentença estrangeira. São Paulo: Saraiva, 1978, p. 123-124; PONTES DE MIRANDA. Comentários ao código de processo civil. Rio de Janeiro: Forense, 1999, Tomo VI, p. 104; e CÂMARA, Alexandre F. Lições de direito processual civil. Rio de Janeiro: Lúmen Juris, 2007, p. 33-34.
} 
a) a Chevron Corporation, empresa norte-americana contra a qual foi proferida a sentença estrangeira, não se encontra situada em território nacional; b) a Chevron do Brasil, pessoa jurídica distinta da requerida e com patrimônio próprio, não integrou o polo passivo da lide originária; e c) não há conexão entre o processo equatoriano e o Estado brasileiro, consoante fundamentação anterior (BRASIL, 2018, p.24).

Extrapolando os limites do juízo de delibação ${ }^{12}$, que deveria se pautar apenas no tocante à presença dos requisitos positivos e na ausência dos negativos, o acórdão questiona as razões de terem os requerentes escolhido a via do reconhecimento da sentença equatoriana no Brasil, a fim de acessar patrimônio de sociedade nacional diversa da que fora parte no processo originário, no Equador. Questiona o porquê de os requerentes não terem direcionado o pedido de reconhecimento aos Estados Unidos da América, sede inequívoca da Chevron Corporation. Atribue, em tom de probabilidade, à existência de várias ações de produção antecipada de provas (discovery actions) em diferentes Estados americanos, bem como a Ação RICO, nas quais restou comprovada a ocorrência de fraude e atos de corrupção do processo originário equatoriano. Tais ações tornariam juridicamente improvável sucesso em tentativas de reconhecimento perante a jurisdição americana competente.

Decorrente dessa probabilidade, mais uma vez avançando sobre os tradicionais limites do juízo de delibação, a Corte Especial, concordando com parecer jurídico apresentado pela requerida, endossa as palavras de Ada Pelegrini Grinover, no sentido de repudiar a utilização da jurisdição brasileira como "trampolim" para o acesso e a constrição de bens da requerida existentes em outro Estado. Por outras palavras, uma vez que a sentença equatoriana enfrentaria dificuldades para ser reconhecida e executada nos Estados Unidos da América, pretender-se-ia utilizar a jurisdição brasileira para acesso a bens da requerida constantes naquele Estado. Situação que, além de enfrentar obstáculos processuais, acarretaria desprestígio ao Judiciário brasileiro e reforçaria a inexistência de interesse jurídico na homologação do título equatoriano.

À luz dos argumentos desenvolvidos, a Corte Especial concluiu, outrossim, que a ausência de jurisdição brasileira conduz necessariamente à ausência de interesse processual dos requerentes, uma das condições da ação. Para tanto, reforça que o interesse processual demanda a verificação do binômio necessidade e adequação da prestação jurisdicional, sendo que a via processualmente eleita deve se mostrar apta a satisfazer concretamente a pretensão autoral, o que não poderia ser alcançado sem a intervenção estatal.

No entendimento de André Abbud (2008), a análise do interesse processual deve ser realizada tendo em vista o grau de cognição reduzido, peculiar ao juízo de delibação, portanto, restrito ao deduzido no pedido de reconhecimento da sentença estrangeira, com vistas a verificar se a vantagem pretendida pode ser alcançada à luz do ordenamento pátrio e do exercício da jurisdição nacional. Dessa forma, tendo em vista que a pretensão dos requerentes na ação de homologação é de ver projetados os efeitos da sentença equatoriana na ordem jurídica brasileira, a impossibilidade de sua execução perante a Justiça nacional conduziria a ausência de interesse processual. Fazendo uso das palavras de Vicente Greco Filho (1978, p.124), inexistirá interesse de agir "toda vez que se esteja diante de uma hipótese de falta de interesse para a execução".

Por concluir que no caso em análise não se verificava interesse do Estado brasileiro para a prestação jurisdicional, ausência de jurisdição nacional, nem interesse processual dos requerentes na ação homologatória, a Corte Especial indeferiu o reconhecimento da sentença equatoriana pela ordem jurídica brasileira.

\footnotetext{
${ }^{12}$ Conforme Amílcar de Castro: "Delibação, que vem do latim (delibatio-onis), é tirar, colher um pouco de alguma coisa; tocar de leve, saborear, provar, no sentido de experimentar, examinar, verificar; e, portanto, o que pretende significar em direto processual é que o tribunal, tomando conhecimento da sentença estrangeira, para mandar executá-la, toca de leve apenas em seus requisitos externos, examinando sua legitimidade, sem entrar no fundo, ou mérito, do julgado. É este o sistema adotado no Brasil” (CASTRO, 2004, p. 555).
} 
A conclusão a que chega a Corte Especial, bem como sua fundamentação, põe em evidência os limites do exercício da cognição reduzida característico do juízo de delibação prévio ao reconhecimento de sentenças estrangeiras no Brasil. Se de um lado a Corte se esforça por destacar sua ciência e respeito aos limites formais e objetivos legalmente estabelecidos, de outro acaba por adentrar em analises substantivas em relação a juízos provenientes de jurisdições terceiras, estranhas, inicialmente, ao processo homologatório. Ademais, em uma análise ampliativa, antecipa avaliação de eventual probabilidade de execução da sentença homologada, a fim de a ela condicionar o reconhecimento requerido. As margens tradicionais do juízo de delibação restaram turbadas.

\section{CONCLUSÃO}

A Sentença Estrangeira Contestada n. 8.542/2018, caso Chevron, representa um laboratório no qual ficam evidenciadas as tensões existentes no exercício do juízo de delibação essencial aos pedidos de reconhecimentos de sentenças estrangeiras no Brasil. As bases teóricas e normativas apontam, conforme visto, que o juízo de delibação a ser conduzido em um processo que, embora de natureza contenciosa, tem seu grau de cognição reduzido, restringindo as matérias de defesa, as manifestações ministeriais do Parquet e o julgamento dos magistrados aos requisitos formal e previamente estabelecidos em lei.

Ocorre que, conforme André de Carvalho Ramos (2015), as tensões e os conflitos de direitos são inerentes às pretensões deduzidas em juízo, de modo que direitos fundamentais como o acesso à justiça, material e formal, o contraditório e a ampla defesa, bem como os interesses de reparação por danos ambientais sofridos por comunidades vulneráveis, a preservação da moralidade e a prestação adequada da tutela jurisdicional - posta a salvo de fraudes e corrupções que corroem a justiça das decisões - são trazidos à superfície nas demandas, mesmo face à cognição restritiva da delibação, pondo em crise a perspectiva tradicional vigente.

Em que pese a tentativa da Corte Especial de reforçar a observância dos contornos formais do juízo de delibação, que limitam a invasão das autoridades jurisdicionais no juízo de homologação sobre o mérito já analisado pelo juízo originário da sentença estrangeira, é possível perceber que em várias ocasiões do acórdão foram postas em relevo questões de fundo, como as investigações na jurisdição norte-americana que apontaram fraude e corrupção no processo equatoriano. O representante do Ministério Público Federal, em sua manifestação, foi bem explícito no sentido de pugnar pela denegação da homologação em razão dos resultados apresentados pelas decisões norte-americanas.

Seguindo o entendimento tradicional na matéria, o Ministro João Otávio de Noronha, em seu voto, reiterou a jurisprudência da Corte explicitada no caso Abengoa (SEC n. 9.412/2017), segundo a qual não há qualquer vinculação ou comprometimento da Justiça brasileira com a Justiça de qualquer outro país, cabendo às autoridades jurisdicionais brasileiras realizarem, de forma autônoma e independente, a análise do cumprimento ou não dos requisitos balizadores do pedido de reconhecimento, dentre os quais a não ofensa à ordem pública nacional. Assim, não há que se pretender balizar o juízo de delibação brasileiro pelas decisões das Justiças norte-americana, canadense ou argentina, posto que a Corte Especial deve exercer, autonomamente, seu próprio julgamento sobre a sentença equatoriana homologanda e sua compatibilidade com a ordem pública brasileira.

De todo modo, a conclusão a que chegou a Corte Especial, no sentido de inexistir interesse da jurisdição brasileira na homologação da sentença equatoriana, partiu da premissa de que a Chevron Corporation, sociedade requerida, não possuía registro perante as juntas comerciais nacionais - nem mesmo restou comprovada existência de ativos da empresa no âmbito nacional. $\mathrm{O}$ relator, Ministro Luís Felipe Salomão, tampouco se aprofundou na análise dos vínculos societários estabelecidos entre a Chevron Corporation e a Chevron Brasil Petróleo Ltda., pertencentes ao 
mesmo grupo econômico. Limitou-se a afirmar que a averiguação da engenharia societária adotada não seria compatível com a estreita cognição da ação homologatória.

Ocorre, todavia, que o enfrentamento da relação societária existente entre as sociedades empresárias norte-americana e brasileira poderia ser justamente a base do interesse jurídico dos requerentes na ação de homologação, bem como a existência de interesse jurídico para o posterior processo de execução perante a Justiça Federal. Se por um lado assiste razão ao Ministro Relator quando entende que tal análise substantiva não seria compatível com o juízo de delibação, faltou dar o passo seguinte ao raciocínio para entender que o momento adequado seria o juízo de execução competente, somente possível após a superação da fase de reconhecimento, perante o Superior Tribunal de Justiça.

Ademais, embora tenha dito que não adentraria à "engenharia societária", o fez de forma indireta ao atrelar a ausência de interesse jurídico do Estado brasileiro à inexistência de contato nacional com a demanda da qual se originou a sentença homologanda (BRASIL, 2018, p.24). Os argumentos segundo os quais não seria possível executar no Brasil decisão contra quem não tenha figurado no processo ou fase de conhecimento, nem mesmo empreender execução contra subsidiária por responsabilidades da sociedade principal controladora, têm como pressuposto a relação (ou sua inexistência) entre a Chevron Corporation e a Chevron Brasil Petróleo Ltda.

No que tange aos debates em torno das alegações de fraude e corrupção, cumpre registrar, entretanto, que balizada doutrina aponta para ocorrência de flexibilização na rigidez tradicional do juízo de delibação, especialmente com a finalidade de fazer prevalecer, no caso concreto, a materialização de direitos fundamentais. Nessa toada, poderia a autoridade julgadora, no exercício da delibação, buscar a interpretação adequada do devido processo legal, em conformidade com preceitos fundamentais, a fim de verificar substancialmente sua ocorrência e combater a prática de corrupção no juízo originário da sentença homologanda (RAMOS, 2015). Reitera-se que, frequentemente, o filtro da ordem pública é utilizado para assegurar garantias processuais ${ }^{13}$.

Da mesma forma, pode-se cogitar a análise, ainda em sede delibatória, da ocorrência de eventual abuso de direito na estruturação societária, com objetivo de segregar as sociedades que compõem o grupo econômico de modo que este não seja alcançado por práticas ilícitas isoladas de cada uma delas - ou seja, os lucros seriam compartilhados, mas as responsabilidades, notadamente em face de terceiros, não seriam.

Não se pode negar, a título conclusivo, que todo o contexto de escândalo de corrupção que se tornou o plano de fundo do caso Chevron, inclusive com distintas ações judiciais em jurisdições estrangeiras distintas, principalmente a norte-americana, tenha em certa medida influenciado subjetivamente a análise judicial da SEC n. 8.542/2018. Por outro lado, não gozou do mesmo grau de repercussão e grande influência os danos ambientais que também compõem o contexto do processo originário, no Equador, tampouco as dificuldades dos afetados em alcançar reparações às lesões sofridas. Mesmo em face da existência de dano ambiental envolvendo a Chevron em zona econômica exclusiva brasileira, em $2011^{14}$.

É preciso ter em conta que cada vez mais temáticas transversais se apresentam no âmbito da categorização dos múltiplos interesses que podem ser deduzidos na ação homologatória de sentença estrangeira. A interação frequente das relações jurídicas com mais de uma ordem jurídica, potencializando os pedidos de reconhecimento de sentenças alienígenas numa sociedade que se adensa em nível de aproximação globalizada, demanda um sistema de reconhecimento aberto e

\footnotetext{
${ }^{13}$ Conforme Renata Gaspar: “Assim se afirma porque, na maioria dos casos em que a homologação foi denegada pelos tribunais competentes - antes STF e agora STJ - ao amparo de violação da ordem pública, o foco usado foi o processual, como, por exemplo, por desrespeito à então forma legal de citação da parte residente e domiciliada no Brasil (que se dava cotidianamente antes da entrada em vigor da LBA) e, por último, por se entender que a ausência de motivação da sentença arbitral estrangeira é questão de violação da ordem púbica nacional, por tratar-se de norma de natureza constitucional (GASPAR, 2009, p. 204).

${ }^{14}$ Para mais sobre o caso, vide: VARELLA, 2015, p. 245-247.
}

Revista de Direito Brasileira | Florianópolis, SC | v. 28 | n. 11 | p.351-366 | Jan./Abr. 2021 
dinâmico. As novas normas na matéria, trazidas pelo CPC/15 e pelo Regimento Interno do STJ, deram uma tônica de abertura da ordem jurídica nacional brasileira a essa não tão nova realidade que se amolda. Espera-se que as práticas jurisdicionais sigam esse caminho, não servindo de barreira à evolução necessária que a matéria requerer.

\section{REFERÊNCIAS}

ABADE, Denise Neves. Direitos fundamentais na cooperação jurídica internacional. São Paulo: Saraiva, 2013.

ABBUD, André de Albuquerque. Cavalcanti. Homologação de sentenças arbitrais estrangeiras. São Paulo: Atlas, 2008.

ARAUJO, Nadia de. O STJ e a homologação de sentenças arbitrais estrangeiras: dez anos de atuação. Boletim da Sociedade Brasileira de Direito Internacional, ano 103, v. 103, n. 125-130, Belo Horizonte: Arraes Editores, p. 103-138, 2017.

ARAUJO, Nadia de (Coord.). Cooperação jurídica internacional no Superior Tribunal de Justiça: comentários à Resolução no 9/2005. Rio de Janeiro: Renovar, 2010.

BARBOSA MOREIRA, José Carlos. Comentários ao Código de Processo Civil: (Lei $n^{o}$ 5.869, de 11 de janeiro de 1973), v. V (arts. 476 a 565). 16. ed., rev. e atual. Rio de Janeiro: Forense, 2011.

BELTRAME, Adriana. Reconhecimento de sentenças estrangeiras. Rio de Janeiro: GZ Editora, 2009.

BRASIL. Superior Tribunal de Justiça. Sentença Estrangeira Contestada (SEC) n. 8.542 - EC. Relator: Ministro Luis Felipe Salomão. Corte Especial. Data do julgamento: 29/11/2017. Data da publicação: 15/03/2018.

COELHO, Ricardo. Pôr um preço na natureza para a preservar? Contradições, dilemas e conflitos em torno da extração de petróleo no Equador. In: CENTEMERI, Laura; CALDAS, José Castro (Coord.). Valores em conflito: megaprojetos, ambiente e território. Almedina: Coimbra, p. 89123, 2016.

CASTRO, Amílcar de. Direito Internacional Privado. 5. ed., aum. e atual. Rio de Janeiro: Forense, 2004.

DOLINGER, Jacob. A evolução da ordem pública no direito internacional privado. Tese de Cátedra na Universidade do Estado do Rio de Janeiro. Rio de Janeiro: 1979.

GRECO FILHO, Vicente. Homologação de sentença estrangeira. São Paulo: Saraiva, 1978.

HILL, Flávia Pereira. A homologação de sentença estrangeira de acordo com a Resolução n ${ }^{\circ}$ 09/05 do STJ. Revista Dialética de Direito Processual (RDDP), São Paulo, n. 53, p. 56-73, ago. 2007. 
KNIJNIK, Danilo. Reconhecimento de sentença estrangeira e tutela da ordem pública processual pelo juiz do foro; ou verificação, pelo STJ, do "modo de ser" do processo estrangeiro. Revista de Processo, São Paulo, v. 156, p. 64, fev. 2008.

LEMES, Selma Ferreira. O Superior Tribunal de Justiça Brasileiro e o Reconhecimento de Sentença Arbitral Estrangeira à Luz da Convenção de Nova Iorque de 1958. 2006. Disponível em: 〈http://selmalemes.adv.br/>. Acesso em: $1^{\mathrm{o}}$ jul. 2018.

PEREIRA, Marcela Harumi Takahashi. Sentença estrangeira: efeitos independentes da homologação. Belo Horizonte: Del Rey, 2010

PEREIRA, Marcela Harumi Takahashi. A sentença estrangeira sem fundamentação pode ser homologada? In: Revista de Informação Legislativa, Brasília, v. 43, n. 169, p. 203-231, jan./mar., 2006.

RAMOS, André de Carvalho. Dignidade humana como obstáculo à homologação de sentença estrangeira. Revista de Processo, São Paulo, v. 249, p. 31-55, 2015.

RUSSELL, Kathryn A. Exorbitant jurisdiction and enforcement of judgments: The Brussels system as an impetus for United States action. Syracuse Journal of International Law and Commerce, Syracuse, v. 19, p. 57, 1993.

SOUZA, Nevitton V. Sistemas de reconhecimento de sentença estrangeira no Brasil: panorama e adequação normativos. 2015, 137 f. Dissertação (Mestrado) apresentada ao Programa de PósGraduação em Direito da Universidade Federal do Espírito Santo, Vitória, 2015.

TANAKA, Aurea Christine. O divórcio dos brasileiros no Japão: o Direito Internacional Privado e os princípios constitucionais. São Paulo: Kaleidos-Primus Consultoria e Comunicação Integrada, 2005.

VARELLA, Marcelo D. A necessidade de repensar os mecanismos de responsabilidade ambiental em caso de riscos de vazamento de petróleo na Zona Econômica Exclusiva do Brasil. Revista de Direito Internacional, Brasília, v. 12, n. 1, p. 241 -249, 2015.

VERÇOSA, Fabiane. A (des?) necessidade de homologação de laudos arbitrais estrangeiros após a entrada em vigor, no Brasil, da Convenção de Nova Iorque. Revista de Direito Bancário e do Mercado de Capitais, São Paulo, v. 22, p. 382, out. 2003. 